\title{
Performance and Challenges in the Value Chain of the Anadara tuberculosa Bivalve Mollusk in Ecuador
}

\author{
Eveligh Prado-Carpio ${ }^{1}$, María de Lourdes Olivo-Garrido ${ }^{2} \mathbb{D}$, Manuel Quiñonez-Cabeza $^{3}$, Christine M. Beitl ${ }^{4} \mathbb{D}$, \\ Moisés Martínez-Soto ${ }^{5}$ id and Carlos Rodríguez-Monroy ${ }^{6, *}$
}

1 Facultad de Ciencias Agropecuarias, Universidad Técnica de Machala, Machala 070102, Ecuador; eprado@utmachala.edu.ec

2 Departamento de Ciencias Sociales y Económicas, Escuela de Nutrición y Dietética,

Universidad Central de Venezuela, Distrito Capital, Caracas 1041, Venezuela; lourdes_olivo@yahoo.com

3 Facultad de Ciencias Administrativas y Económicas, Universidad Técnica Luis Vargas Torres de Esmeraldas, Esmeraldas 080102, Ecuador; manuel.quinonez@utelvt.edu.ec

4 Department of Anthropology, University of Maine, Orono, ME 04469-5773, USA; christine.beitl@maine.edu

5 Departamento de Agronomía, Ciudad Universitaria, Núcleo Agropecuario, Facultad de Agronomía,

Universidad del Zulia, Maracaibo 4005, Venezuela; moisesenriquemartinezsoto@fa.luz.edu.ve

6 Departamento de Ingeniería de Organización, Administración de Empresas y Estadística,

Universidad Politécnica de Madrid, 28006 Madrid, Spain

* Correspondence: cmonroy@etsii.upm.es

Citation: Prado-Carpio, E.; de Lourdes Olivo-Garrido, M.;

Quiñonez-Cabeza, M.; Beitl, C.M.;

Martínez-Soto, M.;

Rodríguez-Monroy, C. Performance and Challenges in the Value Chain of the Anadara tuberculosa Bivalve

Mollusk in Ecuador. Sustainability 2021, 13, 10863. https://doi.org/ $10.3390 /$ su131910863

Received: 12 August 2021

Accepted: 25 September 2021

Published: 30 September 2021

Publisher's Note: MDPI stays neutral with regard to jurisdictional claims in published maps and institutional affiliations.

Copyright: (C) 2021 by the authors. Licensee MDPI, Basel, Switzerland. This article is an open access article distributed under the terms and conditions of the Creative Commons Attribution (CC BY) license (https:/ / creativecommons.org/licenses/by/ $4.0 /)$.

\begin{abstract}
The bivalve mollusk, Anadara tuberculosa (Black Shell, in Spanish Concha Prieta), is found on America's Pacific coast, where it is harvested for subsistence and commercial markets. This paper aims to diagnose the performance of the black shell's value chain. We also identify several challenges that must be addressed to improve the sustainability of the black shell fishery in Ecuador. The applied methodology was quantitative and descriptive. Its design was non-experimental, field, cross-sectional and ex post facto. The investigation was carried out from January to October 2019 in the Jambelí archipelago, El Oro province, Ecuador. The study population consisted of 565 individuals, shellfish collectors, shellfish associations managers, traders, and restaurants from the A. tuberculosa production chain. The sample size was estimated at 222 informants. The type of sampling used was probabilistic, random, stratified, and with proportional allocation, with an effective participation rate of those selected of approximately $80 \%$. The questionnaire was applied personally through the structured survey method, in writing, in the work area, and with their consent. The performance of the value chain was diagnosed in the dimensions of productivity, competitiveness, and quality of life, reaching a $75.1 \%$ index, a result that indicates that the value chain has a moderate to good performance level. The competitiveness dimension reached the highest performance, followed by productivity. Quality of life was the dimension with the lowest performance. The value chain can be improved if the following challenges are met: (1) Restoration of the mangrove ecosystem, (2) Promotion of low-intensity shellfish aquaculture, (3) Good sanitary management and purification, (4) Promotion of value-focused ventures, (5) Strengthening of organizations and agreements for the use and custody of mangroves, and (6) Strengthening of institutions that contribute to the advancement of these challenges.
\end{abstract}

Keywords: Ecuador; American Pacific; bivalve mollusks; concha prieta; value chain; productivity; quality of life; competitiveness; mangrove forest

\section{Introduction}

From the Economic Commission for Latin America and the Caribbean (ECLAC) vision, economic and social development requires a progressive structural change aimed at activities with greater productive dynamism, favoring the care of the environment [1]. The concept of sustainability has been gaining ground, joining the supply chain (SC) in its three dimensions: economic, which translates into profitability to operate as a business; social, 
which includes fair, safe, and equitable labor practices; and environmental, which refers to the responsible use of natural resources and the reduction of waste generation and polluting emissions. Environmental sustainability challenges are associated with more sustainable, productive activities in rural areas, emphasizing mitigation and adaptation to climate change [2]. In particular, inclusive growth is promoted by scaling up or complementing activities that produce greater added value [1].

This environmentally oriented approach considers the sustainable supply chain concept to preserve and protect natural resources to ensure their future availability [3]. The value chains of rural goods are usually made up of small producers who face various barriers to increasing productivity and competitiveness.

In the case of this study related to the production of Anadara tuberculosa, some of its main limitations are:

- The deforestation and contamination of the mangrove ecosystem

- Production methods that overexploit this hydrobiological resource (beyond the supporting capacity of the ecosystem in current conditions)

- Low levels of health and safety of the shellfish that is commercialized

- Progressive reduction of production because the system focuses on quantity and not value creation

- Poor fishing communities with low levels of education and social organization

- Scarce institutional support from both the public and private sectors, nationally and internationally.

For these reasons, scholars have suggested that productivity and competitiveness can be achieved through better articulation of the links, incorporating new actors, and economic and social improvements [4].

Sustainable supply chains (SSC) can be seen as managing social and economic impacts and promoting good governance practices along products' supply chain (SC). The ten steps proposed by the United Nations Global Compact (2010) [5] serve as a guide to achieving its sustainability.

The transformation of the productive structure of the SC requires the incorporation of new technologies that are environmentally responsible and mitigate the effect of climate change through the development of bioeconomy strategies, environmental labels, and cleaner technologies, among other things [6]. In addition, it is necessary to apply complementary instruments in matters of education, innovation, and marketing, among other sectors $[7,8]$, which allow an economic escalation of the links and a better articulation between them and between the actors that compose them [9].

The concepts of supply chain, production chain, and value chain are very similar. Supply chains emerge as a concept in engineering, management, and industrial production to respond to supply and industrial distribution problems in key issues, such as transportation, storage, inventories, and others [9].

For its part, the concept of the production chain arises from the perspective of the producer of raw materials, in this case, the farmer, rancher, fisherman, or fish farmer. It consists of the generation of harmonious and balanced relationships with traders and processors so that the risks and the profits are shared. Generally, the traders and processors of food raw materials achieve higher restorations or profit margins, with a lower risk in their activity [10]. The production chain concept emphasizes the producer.

Finally, the value chain is a tool proposed by Michael Porter [11]. It essentially consists of a form of analysis of business or productive activity through which a company or a productive system is broken down into its constituent parts. It seeks to identify sources of competitive advantage in those activities that generate value. It focuses on the full satisfaction of the end customer.

The value chain concept was developed as a tool for competitive analysis and strategy [12]. The value chain and the supply chain are complementary points of the processes that make up a company or business [13]. In the value chain, value is represented by demand, and in the supply chain, it is represented by cash flow. The main difference 
between the supply chain and the value chain is focusing on the customer supply base [14]. Along these lines, sustainable food value chains (SFVC) are proposed as instruments that provide opportunities to overcome poverty in developing countries. They are conceptualized as those agricultural operations, that in a coordinated way add value to products that are transformed into food and sold to final consumers in a profitable manner, providing benefits for society and not permanently consuming natural resources [15].

Different studies have been carried out on the performance of the supply and value chains, the challenges to be achieved, and the improvement strategies with a sustainability approach, which have served as background to this research. Specifically, in Ecuador, the country where this research was carried out, there are different SCs, among which the banana, shrimp, and the black shell stand out, the latter being the object of interest in this article.

In the case of the banana SC, it has been determined that access to the European market has been achieved through the "Eurepgap" certification, through the training of farmers, and the incorporation of good practices. The production chain is organized around a trading and exporting company. However, production continues to be artisanal and simple. Among the challenges posed are applying crop selection techniques to develop plantations with higher productivity and quality, identifying the best practices to increase production, improve quality and reduce the hours involved in managing the crop, advance together with agrochemical suppliers in the validation of specific products, and improving the facilities to order and facilitate the flow of product and packaging supplies and minimize the transfer of personnel [16].

On the other hand, the preference in the international market for Ecuadorian white shrimp is based on the differentiation (quality-price) and its added value. According to figures from [17], although exports have increased in recent years, prices are falling. This situation has forced the sector to reduce the density of planting, also pressured by the difficulties related to the effects of the COVID-19 pandemic. Among the challenges that must continue to be overcome to achieve sustainable productivity are: adjusting to environmental regulations to reduce the externalities that have been generated by the installation of shrimp farms in mangrove areas, the recovery of the areas affected by their activities, research and technological development to manage disease, diversifying the offer with various types of shrimp, continuing to produce higher value-added products, and research and biotechnology.

For this research, the value chain's performance evaluation is considered as the results obtained in a balanced way in terms of productivity, competitiveness, and quality of life by the organizations, entrepreneurs, and workers involved [10,18].

In this sense, productivity is seen as the relationship between the product generated in any production process and a unit of the factor or resource used for a given period [18]. While competitiveness is considered the effectiveness in meeting objectives, the value chain aims to achieve benefits by placing its products on the market [18]. Advances in the participants' quality of life must accompany the beneficial impacts expected as a consequence of increased productivity and competitiveness. This variable identifies certain shortcomings of the population. It characterizes poverty, defined as the situation of those households that fail to gather, in a relatively stable way, the necessary resources to satisfy the basic needs of their members $[10,18]$.

This study assesses the performance of the value chain (VC) of A. tuberculosa, a bivalve mollusk commonly known as blood cockles or black shell found in mangrove forests along the Pacific coast from Mexico to Peru [10,18]. On the Ecuadorian coast, this mollusk is present mainly in the provinces of El Oro and Esmeraldas.

The cultural importance of $A$. tuberculosa lies in the fact that it constitutes the basis of the food diet and source of economic support for some 4000 families of Ecuador that depend directly on the mangrove ecosystems $[10,18,19]$. It is a resource associated with the mangrove forest, and with adequate management, it can contribute significantly to the preservation and expansion of the approximately 160,000 ha currently found in 
Ecuador [20]. While the contribution of this shellfish to the Ecuadorian Gross Domestic Product is small compared with larger commercial sectors like bananas and shrimp, the production and commercialization of $A$. tuberculosa have great potential to satisfy the internal demand of Ecuador. This may further contribute to the expansion of Ecuador's export sector to neighboring countries and the possibility of venturing into the most demanding markets of the United States of America, Europe, and China.

This highlights the relevance of studying this bivalve mollusk's production and value chain for the communities of settlers located on the Ecuadorian coastline since it is their primary means of subsistence. Its commercialization should generate benefits for those involved in this productive activity. This resource is one of the products provided by the mangrove ecosystem since it reproduces naturally in this coastal wetland. Its proper use and management could positively affect the size and condition of the mollusk populations and the other associated species.

This study diagnoses the value chain performance of $A$. tuberculosa. It reveals its potential for a harmonious balance among shellfish collectors, traders, and restaurants, based on the dimensions of productivity, competitiveness, and quality of life [21]. The study further identifies challenges that must be addressed to improve sustainable economic and social use in harmony with the mangrove ecosystem.

Given that $A$. tuberculosa develops in close association with the mangrove forest located on the Ecuadorian coast, as well as other food resources, the sustainable management of this wetland will allow, at the same time, the use of the food resources it offers. It is understood as sustainable management, which allows obtaining reasonable benefits to those involved in the business. Their activities contribute to the maintenance and development of the wetland that supports them socially and economically. Thus, it allows an integral development for local communities in a situation of poverty that is maintained over time in its social, economic, and environmental aspects.

\section{Materials and Methods}

The applied methodology was quantitative and descriptive [22]. Its design was nonexperimental, field, cross-sectional, and ex post facto [23]. This study is the final part of a more extensive doctoral thesis investigation performed by Professor Eveligh Prado Carpio [10].

The research was carried out from January to October 2019 in the Jambelí archipelago, El Oro province, Ecuador (Figure 1), one of the most important shellfish capture areas in the Republic of Ecuador due to its high landing volumes [24], similar to those of the province of Esmeraldas.

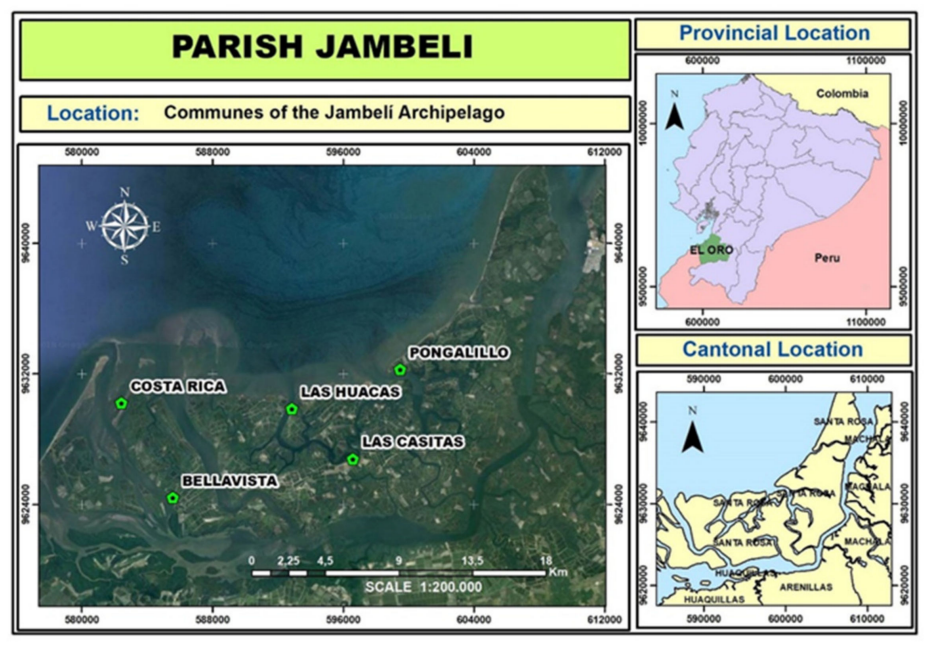

Figure 1. Location of research: Jambelí archipelago, El Oro province, Ecuador. Source: Authors. 
The population under study was integrated by 565 individuals, made up of the strata of shellfish collectors, managers of shellfish associations, traders, and restaurants of the A. tuberculosa production chain, based on the information collected from the Unión de Producción Pesquera Artesanal de El Oro, Ecuador (UOPPAO), from the Asociación de Empresarios de Comercio y Servicios de la Provincia de El Oro, Ecuador, and through the on-site review of the restaurants located on the islands and in the area's coastline.

The sample size was estimated in 222 informants through the formula proposed by [25], using the following equation:

$$
\begin{aligned}
& \mathrm{n}=\frac{\mathrm{PQ}}{\left(\frac{\mathrm{E}}{\mathrm{Z}}\right)^{2}+\left(\frac{\mathrm{PQ}}{\mathrm{N}}\right)}=\frac{(0.5)(0.5)}{\left(\frac{0.0513}{1.96}\right)^{2}+\left(\frac{0.5 \times 0.5}{565}\right)}=\frac{0.25}{0.000685+0.000442}=\frac{0.25}{0.001126}=222 \\
& \text { where: } \\
& \text { - } \mathrm{n} \text { : Sample size } \\
& \text { - P: Probability of success }(50 \%) \\
& \text { - Q: Probability of failure (50\%) } \\
& \text { - Z: Standardized normal table value associated with the confidence level (1.96) } \\
& \text { - E: Maximum permissible error (5.13\%) } \\
& \text { - N: Population size (565) }
\end{aligned}
$$

The type of sampling used was probabilistic, random, stratified, and with proportional allocation, with an effective participation rate of the selected ones of approximately $80 \%$. Those selected who could not participate were replaced by the next individuals on the sampling list.

To collect information, questionnaires were first designed, and validated (opinion of academic experts and managers of the shellfish associations). Four similar questionnaires were applied to each link in the production chain: 138 shellfish collectors, 12 shellfish association managers, 27 traders, and 45 restaurant-cevicherías. Questions were designed to measure the performance construct of the value chain, its respective dimensions, and indicators. The questionnaires can be observed in the doctoral thesis of Professor Eveligh Prado Carpio [10], as well as in the data generated [26].

The questionnaire was applied personally through the structured survey method, in writing, and in each respondent's work area. The research team traveled monthly to collect field information until the estimated sample quantity for each stratum was completed. The interviewer read the questions and possible answers to the respondents, and they responded freely. Finally, the interviewer marked or wrote the responses, as the case might be, on the questionnaire until it was completed. The interviewees gave their consent to participate in the study, which met the ethical standards.

The structured survey questionnaire was administered via face-to-face interviews. The performance construct of the $A$. tuberculosa value chain had three dimensions: productivity, competitiveness, and quality of life.

The original questionnaire was structured in two sections. The first one, of identification or classification, inquired about gender, location, experience, age, and association; with dichotomous, multiple, and open-answer questions. The second section explored the performance construct of the value chain and its dimensions, productivity, competitiveness, and quality of life. Most of the questions were formulated to be answered with the Likert scale.

The predominant measurement scale was the Likert scale with values from 1 to 5 , representing the value of 1 , "never"; the value of 2 , "rarely"; the value of 3 , "sometimes"; the value of 4, "almost always"; and the value of 5, "always". This 5-degree scale was transformed to a 100-point scale through extrapolation to convert it into an index that could be interpreted more intuitively, representing 100 points as the maximum desirable value for each dimension under study. Multiple scales and open questions were also applied for quantitative indicators and the identification of the remains. 
The Concha Prieta Value Chain Performance Index (VCPI) is an original contribution of this research. It is an average of the competitiveness (CI), productivity (PI), and qualityof-life (ICL) indices. The method used to estimate these indices was developed by [27] and integrates the actual variables or response indicators observed in the questionnaire based on the Likert scale. The scale is transformed from the value of 1 to 5 to a value based on 100 points using the following model equation:

$$
\mathrm{VCPI}=\frac{\left(\frac{\sum \text { Points }}{\text { Dimension IC }}\right) * 100+\left(\frac{\sum \text { Points }}{\text { Dimension IP }}\right) * 100+\left(\frac{\sum \text { Points }}{\text { Dimension QLI }}\right) * 100}{\mathrm{n} \text { Dimensions }}
$$

where:

- VCPI: Value Chain Performance Index.

- Points: These are the scores assigned by the interviewees to the different items based on the Likert scale of the applied questionnaires (1 to 5) for each dimension.

- Dimension: Total value ( $5^{*}$ Number of Indicators) of the corresponding dimension (Competitiveness, Productivity, and Quality of life).

- $\quad \mathrm{n}$ : Number of dimensions that apply $(\mathrm{n}=3)$.

The same procedure was applied for each of the dimensions. The scores assigned by the interviewees to each item of the questionnaire in the respective dimension were added and then divided by the maximum value that can be obtained in each dimension ( 5 * Number of Indicators) to finally multiply by 100 . In this way, the Likert scale is transformed into a percentage scale.

According to this research objective, the data recorded in the questionnaires were statistically processed with the SPSS v. 23.0 through univariate tests.

Once the data had been processed, considering the background obtained from the bibliographic review, the results obtained, and the researchers' experience, the most significant challenges for this supply chain were prioritized based on the performance achieved.

\section{Results and Discussion}

\subsection{Performance of the Anadara tuberculosa Supply Chain}

The results are presented and analyzed based on the dimensions of competitiveness, productivity, and quality-of-life, and the subdimensions and indicators that compose them.

In this sense, as an original contribution of this research, the value of the performance index of the A. tuberculosa value chain was estimated at $75.1 \%$. This result indicates that the value chain has a moderate level of performance in terms of competitiveness,

The competitiveness dimension was the one that obtained the highest index with $80.2 \%$, followed by the productivity dimension with $77.1 \%$. The lowest value was in the quality of life dimension, $67.3 \%$ (Figure 2). These results reflect that the human dimension of the value chain performance is the one that has a less favorable performance, based on the evaluated indicators, which will be explained below.

The competitiveness dimension comprises the subdimensions of leadership in costs, differentiated product, and market segment, with their corresponding indicators. The highest levels of competitiveness are achieved, to the extent that production costs are kept below competitive products (shells from neighboring countries) and complementary products (other types of shellfish and seafood in general). Unique and desirable attributes are preserved and developed that allow the experience lived by end-consumers to be rewarding and memorable and to be able to position themselves in specific market segments that value their unique attributes and pay what corresponds to their value. 


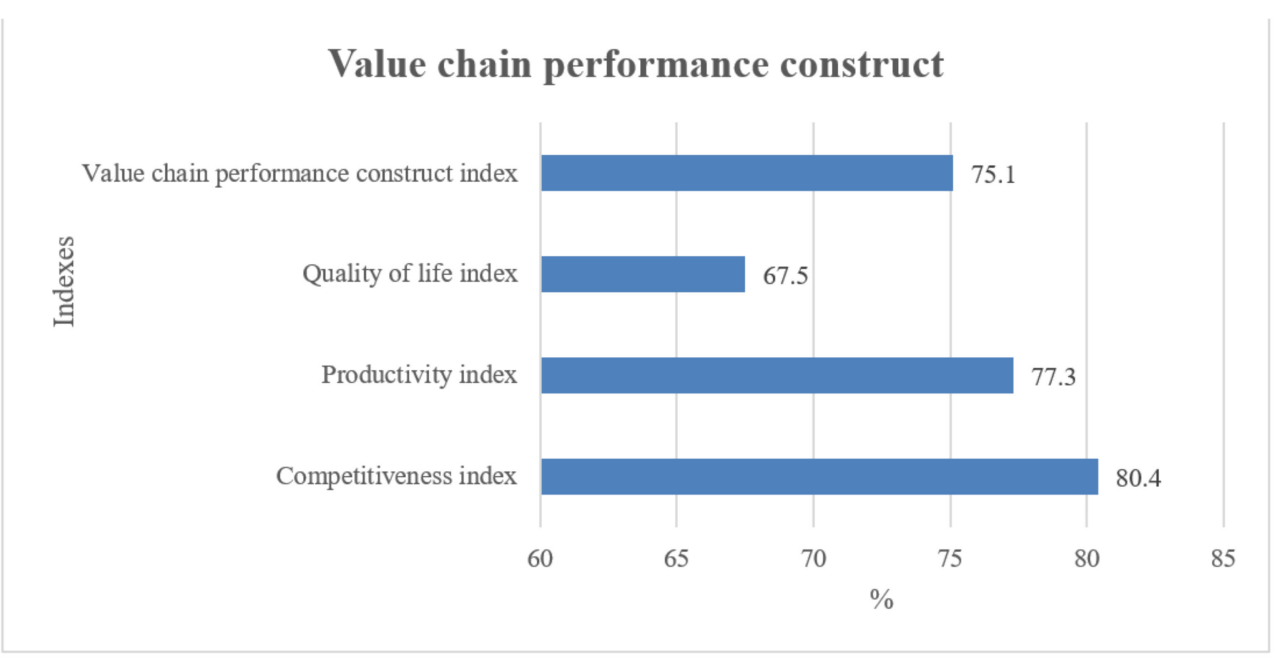

Figure 2. Anadara tuberculosa Value Chain Performance Indexes. Source: authors.

The productivity dimension was integrated by the indicators of the physical productivity subdimension and economic productivity. The productivity dimension investigated whether production was sufficient to satisfy customer demands, as Prado-Carpio et al. $[10,28]$ indicated. In the economic productivity subdimension, it was evidenced that the participants in the $A$. tuberculosa production chain have always experienced moderate improvements in their income (35.4\%). In comparison, $23.1 \%$ experienced that their income has rarely increased [15]. However, the monthly revenue per shell collector was estimated between 427 and 640 USD, a range below the basic family basket in Ecuador, 712.11 USD, equivalent to a $40 \%$ to $10 \%$ deficit. The conclusion is that the income obtained by the shellfish collectors in this activity is not enough to cover the Ecuadorian basic food basket. Therefore, they are in a state of poverty.

Finally, in the quality of life dimension studied by applying the Unsatisfied Basic Needs (UBN) methodology [29], the results obtained indicate that those who participate in the $A$. tuberculosa supply chain have homes with relatively adequate domestic equipment for wastewater disposal. Wastewater is discharged mostly without pretreatment on the coast and the mangrove swamp, negatively affecting the quality of the environment where the mollusk breeds. On the other hand, there is no overcrowding in the houses, but the dwellers' educational level is relatively low, and many families live below the poverty line [9].

\subsection{Challenges of the Anadara tuberculosa Supply Chain}

Based on the performance achieved [30], a set of challenges arises (Figure 3) that impact each of the dimensions under study (productivity, competitiveness, and quality of life). These challenges can enable the improvement and transformation of the $A$. tuberculosa supply chain into a value chain. Among them, the following have been prioritized:

- Restoration of the mangrove ecosystem.

- Introduction of good production practices of the A. tuberculosa, considering both natural populations and new populations derived from low-intensity aquaculture techniques.

- Implementation of systems of good practices of manipulation and purification of A. tuberculosa.

- Promotion of ventures with a value creation approach.

- Strengthening shell organizations and Mangrove Sustainable Use and Custody Agreements.

- Development of an institutional support system that, based on innovation, contributes to advancing the challenges mentioned above. 


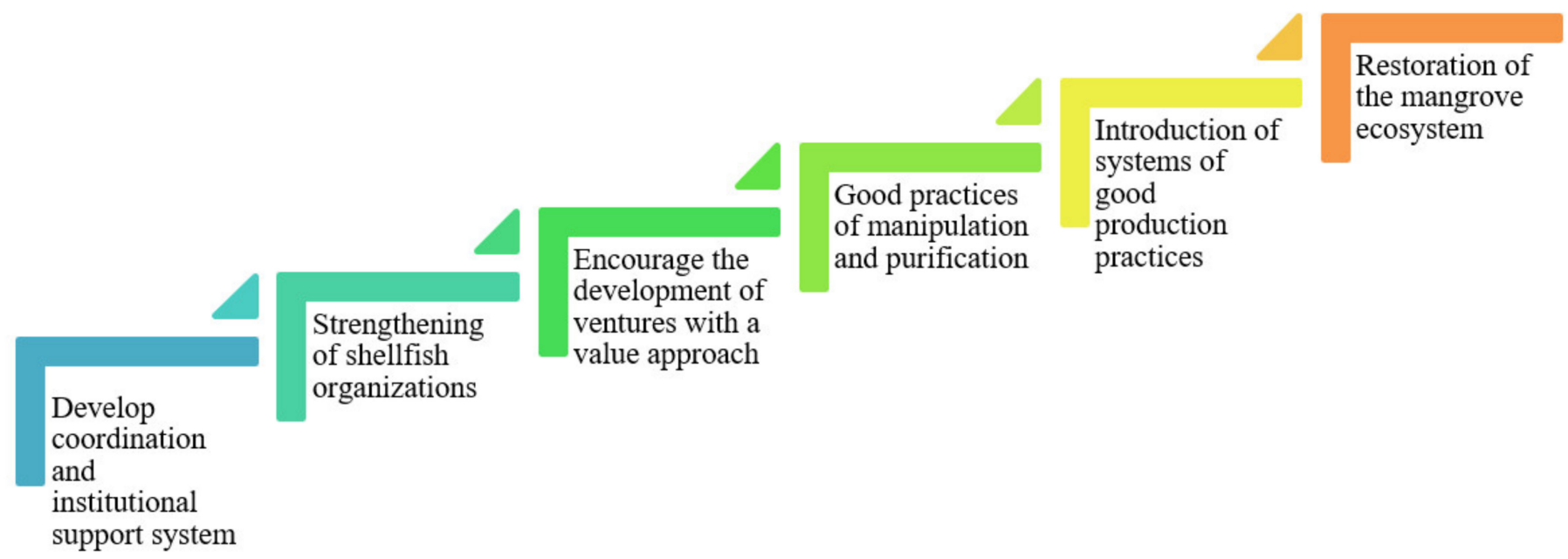

Figure 3. Anadara tuberculosa value chain challenges. Source: authors.

The infographic presented in Figure 3 is made up of a ladder where each step represents a support structure that facilitates the fulfillment of the next step, which shows higher levels of complexity and approach to achieving the challenges posed for closing the gap between the current conditions of the A. tuberculosa production chain and the desirable conditions of the value chain performance construct.

Developing an institutional support system based on innovation will contribute to strengthening shellfish organizations and the Mangrove Sustainable Use and Custody Agreements. These will facilitate the development of economic and social enterprises focused on value creation. The institutional support system, the social organizations of shellfish collectors and other actors in the value chain, and the development of enterprises will contribute significantly to the implementation of systems of good practices for handling the shellfish. They will also encourage the introduction of good shellfish production practices either by traditional approaches based on natural production or by new production systems based on low-intensity aquaculture techniques. Finally, they will contribute to the restoration of the mangrove ecosystem through the progressive reduction of pollution and overexploitation and the expansion of the mangrove surface through replanting.

Challenge Number 1. Restoration of the mangrove ecosystem.

The integrity of the ecosystem must be addressed to achieve and maintain a healthy supply chain of mangrove products. The mangrove ecosystem provides many goods and services (protection, food provision, $\mathrm{CO}_{2}$ capture, blue carbon reservoir, wood production, habitat for biodiversity), so promoting its sustainable use is a priority.

Mangroves reduce vulnerability to climate change by capturing greenhouse gases, carbon sequestration and storage, erosion control, protection against extreme events, soil formation, and water quality improvement [31-33].

If the homeostasis of this crucial coastal wetland is preserved and complemented with sustainable management, the development of associated species will be allowed during their life cycle. By achieving the sustainable use of the mangrove, it will be possible to obtain a better natural production of the black shell and other biotic resources it supports (fish, crabs, shrimp, and snails, among others), necessary to improve the food situation of populations. However, the degradation and reduction of mangrove coverage are affecting its capacities.

The mangrove forests located on the coastal strip have been subjected to adverse impacts from shrimp breeding, tourism, industrial production, and urban growth, among others). These activities affect the watersheds with deforestation and burning, and change the course of tributaries, and runoff of domestic, industrial, and agricultural discharges without adequate treatment [32]. 
In Ecuador, shrimp farming stands out as one of the practices with the most intense effects on mangroves since large areas are cut down to install breeding pools, and significant quantities of chemical products are used (food, fertilizers, pesticides, and antibiotics), with the direct contamination of the ecosystem.

Pollution caused by domestic effluents without treatment and containing concentrations of nitrogen, phosphorus, chlorides, sulfates, carbonates, and organic compounds can also present microbiological pathogens that are a human health risk [34,35].

The most applied practice to recover the mangrove surface has been reforestation. In this sense, $[36,37]$ point out that this technique, whether by direct planting, seedlings produced in the nursery, dispersal by casting, or transplanting individuals from a nearby area in good conditions, has given good results in Mexico.

With associated actions, hydrological rehabilitation is another of the most frequently implemented strategies in mangrove restoration [38].

Every restoration project must include a program for diagnosis, implementation, monitoring, and training for those involved [39,40].

Based on these considerations, to achieve the restoration of the mangrove ecosystem, the following strategic objectives are proposed:

- Preventing, controlling, or mitigating all those impacts generated by anthropic pollution sources from industrial, agricultural, and domestic activities without physical chemical bacteriological treatment in all landscape units that make up the watersheds of mangrove forests.

- Prohibiting the establishment of shrimp pools in the areas of influence of the mangrove ecosystem or, in any case, when new spaces are established in these sensitive areas compensate for the negative impact with the sowing and replanting of mangrove surfaces.

- Improving the disposal of solid domestic waste mainly, favoring the reduction, reuse, and recycling.

- Developing programs for the maintenance or improvement of the environmental quality of the mangrove ecosystem will allow for a lower pollutant load towards the shellfish and, therefore, the final consumer.

- Promoting restoration/reforestation actions of the mangrove ecosystem and its truly comprehensive associated resources.

- $\quad$ Promoting integrated forest-aquaculture systems, where mangroves are planted near and within aquaculture pools.

- Reinforcing the role and coordination with local communities to achieve success in mangrove ecosystem recovery programs.

- Considering carbon bonds or carbon credits as a strategy that allows mitigating the generation of greenhouse gases, benefiting companies that do not emit or reduce emissions and making those that surpass their allowed emissions pay.

Challenge Number 2. Introduction of sound production practices systems of the A. tuberculosa, both natural and new populations derived from low-intensity aquaculture techniques.

The $A$. tuberculosa grows and develops naturally, closely linked to the mangroves located on the coastline. Maintaining the balance of this ecosystem will allow its sustainable production. However, the mangroves are subject to intense pressures, as mentioned previously, which negatively affect the natural production of the A. tuberculosa, coupled with their overexploitation in some Ecuadorian coastal sectors.

Therefore, based on the existing scientific experiences and the successful ones of the shellfish collectors, it is recommended to develop good practices that contribute to the restoration of the mangrove forest and shellfish production. The goals should be to preserve and stimulate the natural production of the black shell in the mangrove areas less affected by pollution and deforestation. The introduction of low-intensity aquaculture techniques in the most affected areas, which require an additional effort to stimulate mangrove restoration and $A$. tuberculosa breeding, should also be considered. 
On the other hand, some studies have shown that the growth rate of $A$. tuberculosa is quite slow. It varies between 1.54 [41] and $1.875 \mathrm{~mm} / \mathrm{month}$ [42]. It takes between one or two years to reach the commercial size depending on growth conditions. In these circumstances, sustainable aquaculture represents food and an economical alternative for families dependent on this resource and can represent a particular safety net for families dependent on this resource.

In this sense, to preserve the natural production of the black shell in the mangrove areas less affected by pollution and deforestation, the following strategic objectives are proposed:

- Encouraging the natural production of $A$. tuberculosa in the areas least affected by anthropic activity through management practices. Among these practices, we can include self-aging or designation of periods in which they are not collected, scheduling of shellfish collecting activities, rotation of extraction areas, and pens to extract the shellfish in demarcated areas $[43,44]$.

- Regulating the extraction of seeds from banks in times of exceptional abundance or scarcity, based on purely technical criteria.

- Establishing production goals in the different collecting areas, based on the dynamics of the market and the preservation of the resource, complying with the $45 \mathrm{~mm}$ total length (TL), which is established by the Ecuadorian standard for its extraction.

- Applying controls with sieves in the manner of a table with iron mesh where all the shellfish collectors deliver their daily catch to avoid the extraction of shells from the mangrove with a size smaller than $4.5 \mathrm{~cm}$ total length. Small shellfish that fall through the screen should be seized and returned to the mangrove. Another option is applying sanctions on the number of shellfish or reducing the number of days of shellfish collection for those who do not comply with the norm.

- Carrying out a geographical delimitation of the coastal sector that considers reforestation, research, and commercial extraction areas.

- Encouraging the production of seeds in hatcheries since it would reduce the pressure on natural banks, to repopulate areas with reduced $A$. tuberculosa populations.

- Strengthening capacities for prevention, control, and monitoring of aquaculture health.

- Promoting training programs, including technical training to manage repopulation areas, natural banks, and seed collection.

- Designing, disseminating and improving good practice guides for the extraction and production of $A$. tuberculosa, both for traditional systems based on extraction and the development of new production systems based on low-intensity aquaculture techniques. Such practices should improve production in terms of quantity, quality, and restoration of the mangrove ecosystem.

- Encouraging the creation of a designation of origin for the Ecuadorian black shell.

Challenge Number 3. Implantation of systems of good practices of manipulation and purification of the A. tuberculosa.

The world production of mollusks has been negatively affected by diseases that have become a restriction for the development and sustainability of their culture and exploitation [45].

The shellfish must be free of microorganisms or viruses in concentrations that may constitute a health hazard. It must be free of toxins and chemical compounds such as heavy metals and organic compounds from industrial activities [46].

In bivalve mollusks, their safety is of great importance since these species feed by nonselective filtration mechanisms, and therefore they can become concentrators of various pathogens [47]. The preferred form of consumption of bivalve mollusks is raw, without cooking. Therefore, there is a potential risk to the health of the consumers.

Purification is a process that consists of keeping the mollusks in clean seawater tanks in conditions that allow maximizing the natural filtration activity and thus expelling the intestinal content. There are limitations to the types of microbes that can be successfully killed through this process [47]. 
In the case of the black shell, it is recommended to carry out the purification practice to achieve a safe product, of higher quality, with added value, that is more competitive. It can also offer greater profits to producers and marketers and their foray into the international markets of North America, Europe, and Asia.

To face this challenge, it is recommended to advance in the development of the following strategic objectives:

- Carrying out studies and monitoring that make it possible to accurately diagnose the quality of the shell that is extracted in the different extraction and production areas defined in the geographical delimitation.

- Implementing systems of sound A. tuberculosa processing and handling practices based on techniques such as self-purification.

- Carrying out pilot studies to determine the costs involved in establishing the system of good practices for handling and purifying the shell.

- $\quad$ Promoting the access of the purified and processed shell to more demanding markets in terms of health and safety.

- Encouraging levels of competition in the A. tuberculosa market based on quality and prices.

- Incorporating innovation and technology to ensure that the highly perishable shell reaches all Ecuador and neighboring countries under the recommended safety conditions.

- Demanding compliance with safety from its production or extraction to its sale to the final consumer, ensuring that the product is not exposed to new contaminants and that adequate measures are taken for its conservation.

Challenge Number 4. Encourage the development of ventures with a value approach. As previously mentioned, the production of the $A$. tuberculosa is a traditional business in which the members of the families of shellfish collectors, fishermen, and residents of the coastal areas participate, obtaining income from this activity. In this sense, developing an entrepreneurial and business culture in the participants with a value chain approach with social justice and equity is necessary.

The $A$. tuberculosa reception, storage, and distribution activities are carried out by the collecting and wholesale intermediaries, who distribute then the shellfish to the retail markets and restaurants. Within these internal logistics, it is convenient for the shellfish collectors to have greater participation in the commercialization margin. This could be achieved through the existing shellfish organizations.

In San Lorenzo, Esmeraldas, Ecuador, shellfish collectors usually sell the shellfish for between 8 and 10 USD for one hundred units, depending on the season [48]. The establishments that receive their production sell it to intermediaries for between 10 and 12 USD in the same municipality. According to the research performed [48], the traders earn 1 dollar for every hundred units and the storage warehouse that buys the least amount per week is an average of 106,000 shells, representing 1060 USD. If their average profit is one dollar per hundred units, they earn 1060 USD per week. This translates into a monthly income of 4240 USD, a much higher value than the income obtained by shellfish collectors. However, the best price at which the traders sell, 0.12 USD per shell, is still much lower than the price charged by restaurants and cevicherías in Ecuador, and the prices at which the shellfish are sold in Peru exceed USD 0.50 per unit.

A positive experience to face this problem of inequity in the marketing margins in the value chain was developed by the Association of Shellfish Collectors and Underwater Fishing of Ancón, in Peru [49]. It was possible to confirm through an investigation that the higher the shared value practices, the higher the sustainability in its value chain. Shared value implies innovation and a significant benefit for society that is also of value for the business. It can create shared value in three different ways that complement each other, constituting a virtuous circle: conceiving new products and markets, redefining productivity in the value chain, and building local clusters where it operates. At the same time, it requires a difficult balance between social needs and business benefits [50]. 
Transforming the mentality of the shellfish collectors and the rest of the participants in the production chain of the A. tuberculosa towards a focus on entrepreneurship and value chain is one of the most critical challenges to overcome. This transformation has been promoted in the different fishing and aquaculture production chains in the European Union, including bivalve mollusks. The aim is to increase value, create jobs, attract young people to the business, and promote innovation in all phases of the supply chain for fishery and aquaculture products [51].

In this context, entrepreneurship can be defined as a social and knowledge strategy for developing skills that allow the economically active population to carry out business projects for self-employment with a greater degree of certainty and possibilities of a better quality of life [52]. Therefore, to overcome this challenge in the A. tuberculosa value chain in Ecuador, the application of good entrepreneurship practices and the development of strategic objectives mentioned below is recommended:

- Strengthening the organizational or associative processes that allow shells to market their catch directly to end customers.

- Improving knowledge of the market, making it more transparent through the registration of commercial operations.

- Preparing a business plan at the national, provincial, and municipal levels and mangrove areas assigned to the shellfish collectors and fishers in the sustainable use agreements.

- Preparing a marketing plan for A. tuberculosa that stimulates its consumption nationally and internationally.

- Diversifying the market with innovative products based on fresh and processed consumption and the alternative use of shells for industrial and artisanal purposes. Additionally, the development of tourist routes based on shellfish gastronomy, the contemplation of the mangrove, and its capture and collection adventure should be considered.

- Establishing training programs aimed at shellfish collectors and other participants in the production chain of the black shell, stimulating the formalization of this social and productive activity and entrepreneurship at the micro-business level.

- Promoting a seedbed of family businesses to develop the black shell business and its value chain at the family level.

Challenge Number 5. Strengthening of shellfish organizations and Mangrove Sustainable Use and Custody Agreements.

According to [53], in the 1990s, popular movements in defense of the mangrove ecosystem began to grow and consolidate in new civil society institutions dedicated to resource management, mangrove reforestation, and raising awareness among the people about their property rights. In this sense, the Ecuadorian State began to recognize the rights of the ancestral users of the mangrove according to Executive Decree 1102 of 21 July 1999.

In 2000, the Ecuadorian State granted the first concession of 579 ha of mangroves for ten years to the Costa Rica Association in El Oro for its conservation and sustainable use of resources, such as the A.tuberculosa. Currently, there are dozens of concessions of this type in Ecuador that represent community management of natural resources. Such is the case of the mangrove ecosystem and A. tuberculosa. The results show that mangrove stewardship, cooperation among users, and institutional collaboration are strategies that have improved the preservation of this ecosystem and the sustainable use of the CP [54,55]. However, despite the attempt to conserve the surface of these forests through the Sustainable Use and Mangrove Custody Agreements, the negative impacts of overfishing have not been alleviated [56].

This unwanted situation probably has as its causes that: (1) not all the associations are well-organized enough to control the minimum catch size or to carry out a self-closure; (2) not all concessionaires are qualified to assume complete control of their areas in custody, for which other collectors and fishers freely enter these areas; (3) there are not enough collaboration and control mechanisms, since the necessary equipment to effectively manage 
the mangrove supervision is limited; and (4) there is scarce or no presence of fisheries inspectors in the landing sites of the mangroves for the control of the minimum commercial size of the shells.

In the province of El Oro, Ecuador, the Management Effectiveness of Sustainable Use Agreements and Mangrove Custody "AUSCM" [57] was studied, showing that AUSCM is an effective tool for the conservation of the mangrove ecosystem and the economy of the ancestral communities in the province of El Oro. There are significant differences between the 20 custody areas. The Sociomanglar incentive is effective in improving compliance with agreements, as well as organizational strengthening. However, overexploitation of bio-aquatic resources and pollution persist, requiring more significant support and interinstitutional coordination from control entities. Part of the issue could be explained because Sociomanglar programs are not designed to manage fisheries; instead, they are designed to address forest conservation. More ecosystem-based management and community-based approaches could allow for the design of more locally appropriate management strategies. Based on the challenges of user organizations, a set of strategic objectives are proposed to meet and overcome the challenge, among which the following stand out:

- Elaborating alternative development projects for the independent shellfish gatherers and associations that do not have custody of the mangrove to reduce the negative impact of excessive shellfish collecting.

- Motivating and support the defense and restoration of the mangrove forest based on strengthening the activities of the organized communities of shellfish and fishers.

- Promoting the figure of mangrove custodians through agreements between the communities and the government, which contain specific action plans to meet the challenges and strategic objectives set out in this research.

- Integrating communities and authorities to face the insecurity problem of people and property in the extraction areas and on the boat transportation routes.

- Through the National Network of Users and Ancestral Custodians of the Mangrove in Ecuador setting up a non-governmental organization to defend the restoration of the mangrove ecosystem and its sustainable use. The organization should have sufficient institutional weight to manage the conflicts that arise with the companies' shrimp farms and other stakeholders and the capacity to establish links with social organizations with similar purposes at the international level.

- $\quad$ Promoting and coordinating water transport routes that take the shellfish collectors to the extraction areas in a programmed and organized manner with quality and competitive prices.

- Promoting developing a national registry of shellfish collectors, association managers, traders, and restaurant-cevicherías, culminating in granting a license or certificate that authorizes the extraction, commercialization, and elaboration of shellfish dishes enabling the supervision and good performance of their work.

Challenge Number 6. Develop coordination and institutional support system that, based on innovation, contributes to advancing the previous challenges.

The five previous challenges will be easier to achieve if there is an innovative system based on government institutions, the economic sectors, academia, international cooperation, and the organized community that contribute to the best performance of the A. tuberculosa value chain. As a reference, some experiences are presented.

Chile is widely acknowledged as the regional leader in aquaculture production [58]. The mussel farming industry is the leading mollusk-growing country and has shown remarkable growth and development. The National Council of Innovation has promoted these results for competitiveness (CNIC), whose fundamental mission has been to design and facilitate a national innovation strategy and propose public policies that promote national development based on knowledge and innovation. For this purpose, the Chilean government has invested around USD 120 million in aquaculture research and development, reaching an average public expenditure of USD 14 million per year. The main areas served were farming technologies, productivity, and product quality. 
In El Salvador, the government has developed the Project for the Development of Mollusk Aquaculture, with the support of the Japanese government, through the Japan International Cooperation Agency (JICA). The objective is to improve the quality of life model mainly through mollusk aquaculture activities, based on the awareness of natural resource management. The project conducted trials to establish artificial seed production technology, the technique of the intermediate culture, and the culture for fattening shellfish (A. tuberculosa) obtained from the Guide for the Production of Anadara spp [59].

In Ecuador, experiences have also been developed in which international cooperation has improved the production and marketing system of $A$. tuberculosa [60]. Likewise, through the Public Institute for Aquaculture and Fisheries Research, the Ecuadorian government publishes reports to determine the fishing exploitation of the shellfish resource in the mangrove ecosystem and generate management recommendations for its sustainability [61]. Additionally, through the Ministry of the Environment, the Socio Bosque Incentives Program, Mangrove Social Chapter has delivered monetary incentives to more than 70 community organizations dedicated to restoring and sustainable management of the mangrove ecosystem [62].

For their part, Ecuadorian universities also carry out actions in favor of the hydrobiological resource $A$. tuberculosa, through investigations that have served to diagnose the exploitation of the resource and propose project improvement actions. Such is the case of the Technical University of Machala and the Luis Vargas Torres de Esmeraldas Technical University, which have published more than 200 studies related to A. tuberculosa.

Finally, the Ecuadorian private business sector is also making its contributions to the development of this value chain. Such is the case of El Pailón company, which made the first export of $50 \mathrm{~kg}$ of black shells on 18 May 2021 to the United States of America and expects to export one ton per week [63].

Based on these experiences and the challenges and strategic objectives to be achieved, creating a national coordination body in Ecuador is necessary to integrate the interested parties in mangrove restoration and strengthen the A. tuberculosa value chain (Figure 4).

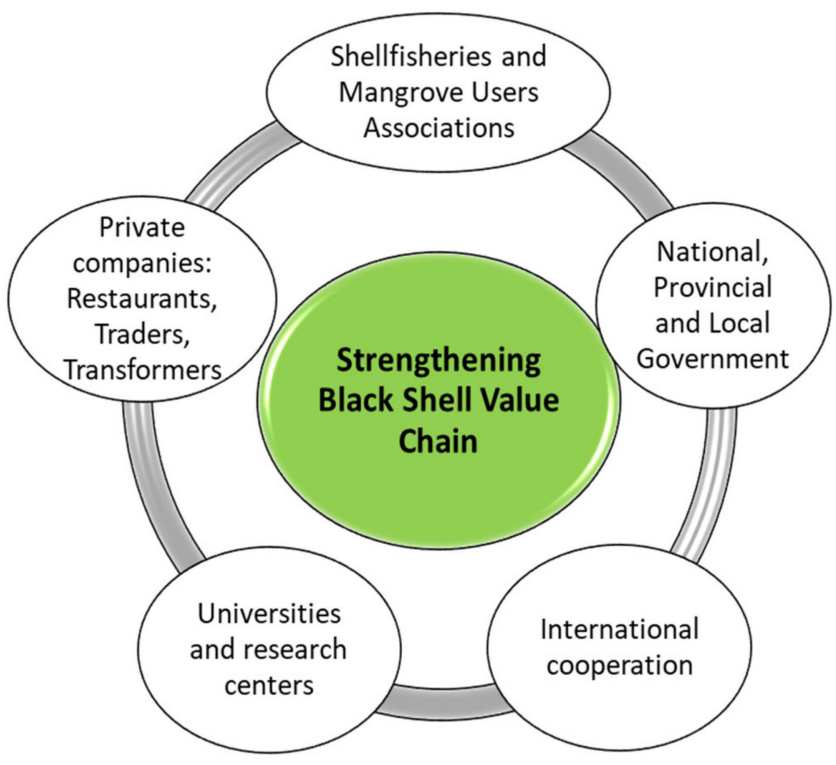

Figure 4. National association model for strengthening the Anadara tuberculosa value chain. Source: Authors.

This coordination body could represent shellfish collectors, universities, private companies, and enterprises dedicated to the commercialization and preparation of the shellfish, the government, and international cooperation. The aim is to coordinate actions' innovations to strengthen the value chain of the Concha Prieta and the restoration of the mangrove forest. Among the main strategic objectives of this challenge are: 
- Coordination at the national, provincial, and municipal levels to fulfill the challenges and strategic objectives set.

- Seeking and allocating the necessary resources in an optimized way to develop actions that are planned jointly or individually.

- Exploring financing mechanisms to fulfill its purposes, either nationally, internationally, or through the value chain itself, establishing a contribution by the economic actors involved.

- Preparing the national business development plan for the A. tuberculosa in correspondence with the preservation and restoration of the mangrove ecosystem.

- Presenting semiannual reports on the progress of their actions and the business situation of the A. tuberculosa.

- Generating new knowledge through basic and applied studies on biological, technical, productive, social, economic, and market aspects necessary to comply with the elaborated planning.

\section{Conclusions and Recommendations}

Based on the objectives of this research, the following conclusions and recommendations are presented:

- The value chain of the $A$. tuberculosa is composed of links between shellfish collectors, shellfish association managers, traders, and restaurants-cevicherías and presents a moderate to good performance based on the diagnosis made of its three dimensions, competitiveness, productivity, and quality of life.

- The value obtained for the performance index of the A. tuberculosa value chain (75.1\%) indicates that it has a moderate level in terms of competitiveness. It should be noted that the competitiveness dimension was the one that achieved the best performance when compared with the productivity dimension that registered an intermediate performance level and the quality-of-life dimension, which obtained the lowest performance level. Therefore, there is a gap between the optimal conditions proposed by the literature and the one observed and quantified through this study.

- The competitiveness of the black shell business lies in the unique characteristics that make it an attractive and highly demanded product. Even so, it is threatened by different factors, which could be adequately managed if progress is made in meeting the challenges posed in this research.

- Productivity is limited by the loss of surface and contamination of the mangrove ecosystem, which results in low income for the shells and remains of participants in this value chain.

- The quality of life, which was the dimension that achieved the lowest performance, is affected by the low income obtained mainly by shellfish collectors and the effects of pollution and loss of mangrove surface. The low levels of innovation, ventures with added value, socio-productive organization, and institutional support are also significant factors.

- In this research, the need to apply sustainable development guidelines in the $A$. $t u$ berculosa business was determined since for local people to obtain an economic benefit from their subsistence activity (economic dimension), which generally involves the entire family group (social dimension), it is required to adequately take advantage of the shellfish resource associated with the mangrove ecosystem. This allows the wetland to develop appropriately and provide the necessary food resources (environmental dimension).

- The diagnosed performance and observation of the $A$. tuberculosa value chain allowed identifying the main challenges for its strengthening and for mangrove preservation, which are the following: (1) the restoration of the mangrove ecosystem; (2) the introduction of good production practices of the A. tuberculosa, both of natural populations and new populations derived from low-intensity aquaculture techniques; (3) the implementation of good practices for manipulation and purification of the A. tuberculosa; 
(4) the promotion of ventures with a value creation approach; (5) the strengthening of shellfish organizations and Mangrove Custody and Sustainable Use Agreements and, lastly, (6) the development of an institutional support system that, based on innovation, contributes to the advancement of the challenges mentioned above.

- For each of the challenges and strategic objectives, it is recommended to perform research and generate master documents that help clarify the optimal method of their application in the Ecuadorian context and serve as a guide for the rest of the countries that produce and commercialize the A. tuberculosa. This is recommended for future research.

- The limitations of the study are of a logistical and conceptual nature. Logistically, the limitations arise due to the extensive area under investigation and the difficult access, mainly by small boats to the production areas. From the conceptual point of view, the limitations arise from applying a complex construct such as the value chain to a rudimentary and small production chain like the $A$. tuberculosa value chain.

Some economic policy recommendations related to strengthening the value chain and meeting the challenges posed are the following:

- Seeking sources of national and international financing to preserve the mangrove ecosystem and its sustainable use by producing the $A$. tuberculosa and other species present in the mangrove. Among these, the raising of funds related to the $\mathrm{CO}_{2}$ market offered in multilateral organizations stands out.

- Establishing some registry through guidance systems that allow quantifying the amount of shellfish produced and sold nationally and exported to the neighboring countries of Colombia and Peru. This guidance system can be financed with the payment of small fees by those who buy the shells.

- Promoting the responsible consumption of seafood at the restaurant level in terms of quality and size. A differentiated pricing policy based on quality standards could contribute to this objective. Higher quality means better prices.

- Shrimp companies and other industries that have benefited from the deforestation and contamination of the mangroves should pay some fees collected at the level of local governments or NGOs to invest in expanding the mangrove surface and its decontamination. Likewise, they must strengthen their social responsibility policies concerning their production environment.

Author Contributions: Conceptualization, E.P.-C. and M.M.-S.; methodology, E.P.-C. and M.M.S.; validation, E.P.-C. and M.M.-S.; formal analysis, M.d.L.O.-G., M.M.-S., C.M.B. and C.R.-M.; investigation, E.P.-C., M.d.L.O.-G., M.M.-S., C.R.-M., C.M.B. and M.Q.-C.; data curation, E.P.-C. and M.M.-S.; writing—original draft preparation, M.d.L.O.-G., M.M.-S., C.R.-M., C.M.B. and M.Q.-C.; writing-review and editing, M.d.L.O.-G., M.M.-S., C.R.-M. and C.M.B.; funding acquisition, E.P.-C. All authors have read and agreed to the published version of the manuscript.

Funding: We thank Universidad Técnica Luis Vargas Torres de Esmeraldas, Ecuador, for financing the APC of this article.

Institutional Review Board Statement: Not applicable.

Informed Consent Statement: Informed consent is not applicable.

Data Availability Statement: Links to publicly archived datasets analyzed or generated during the study. The questionnaires designed and applied for this research were done in Spanish. They were published by Eveligh Prado-Carpio, as well as the data (responses), in the following web locations: Accessible in: https://www.researchgate.net/publication/353352826_Tesis_Doctoral_ en_el_Doctorado_de_Ciencias_Agrarias and in the published data accessible in: https://www. researchgate.net/publication/354600788_Data_Tesis_Doctoral_Eveligh_Prado-Carpio, accessed on 20 September 2021.

Acknowledgments: We thank the Union of Artisanal Fisheries Production of El Oro, Ecuador (UOPPAO), from the Association of Commerce and Services Entrepreneurs of the Province of El Oro, Ecuador, for supporting the compilation of basic information through questionnaires. 
Conflicts of Interest: The authors declare no conflict of interest.

\section{References}

1. Padilla, R.; Oddone, N. Manual Para el Fortalecimiento de Cadenas de Valor; LC/MEX/1.1218; CEPAL-Comisión Económica para América Latina y el Caribe: Mexico City, Mexico, 2016; pp. 1-114. Available online: https://www.cepal.org/es/publicaciones/40 662-manual-fortalecimiento-cadenas-valor (accessed on 2 January 2021).

2. Quiroz Estrada, V. Desafíos en materia de desarrollo productivo en el espacio rural de Centroamérica y la República Dominicana. In Política Industrial Rural y Fortalecimiento de Cadenas de Valor; Padilla Pérez, R., Ed.; Libros CEPAL N 145, LC/PUB.2017/11-P; Comisión Económica para América Latina y el Caribe (CEPAL): Santiago, Chile, 2017; pp. 25-62, ISBN 978-92-1-0585897. Available online: https://www.cepal.org/sites/default/files/publication/files/41850/S1700275_es.pdf (accessed on 15 March 2021).

3. Sisco, C.; Chorn, B.; Pruzan-Jorgensen, P.M. Sustentabilidad de la Cadena de Suministro una Guía Práctica Para la Mejora Continua; Pacto Mundial de la ONU y Negocio para Responsabilidad Social, United Nations Global Compact-BSR. 2010, pp. 1-35. Available online: http:/ / pactoglobal.org.py/uploads/h4dVQ5.pdf (accessed on 12 March 2021).

4. CEPAL-Comisión Económica Para América Latina y el Caribe. Política Industrial Rural y Fortalecimiento de Cadenas de Valor; Padilla Pérez, R., Ed.; Libros CEPAL N 145, LC/PUB.2017/11-P; Comisión Económica para América Latina y el Caribe (CEPAL): Santiago, Chile, 2017; pp. 1-245, ISBN 978-92-1-058589-7. Available online: https://www.cepal.org/sites/default/files/ publication/files/41850/S1700275_es.pdf (accessed on 15 March 2021).

5. Pacto Mundial de Naciones Unidas. United Nations Global Compact. Una Llamada a la Acción Para Empresas Sostenibles. United Nations Global Compact. Sustentabilidad de la Cadena de Suministro. Una Guía Práctica Para la Mejora Continua. Pacto Mundial de la ONU y Negocio Para Responsabilidad Social. 2010. Available online: https:/ /www.pactomundial.org/wpcontent/uploads/2018/02/Flyer-New-Strategy-GC-2018_20180126-1.pdf (accessed on 2 March 2018).

6. Instituto Interamericano de Cooperación para la Agricultura (IICA). Encuentro de Ministros de Agricultura de las Américas. In Proceedings of the Decimoctava Reunión Ordinaria de Documento Técnico “Una Productividad Competitiva, Incluyente y Sustentable: Oportunidad Para el Continente Americano", Cancún-Riviera Maya, México, 19-23 October 2015; IICA/JIA/Doc. 370 (15) la JIA. Available online: http:/ / repositorio.iica.int/handle/11324/3174?locale-attribute=pt_BR (accessed on 24 May 2020).

7. Padilla Pérez, R.; Oddone, N. Metodología Para el Fortalecimiento de Cadenas de Valor. In Política Industrial Rural y Fortalecimiento de Cadenas de Valor; Padilla Pérez, R., Ed.; Libros de la CEPAL N ${ }^{\circ} 145$ (LC/PUB.2017/11-P); Comisión Económica para América Latina y el Caribe (CEPAL): Santiago, Chile, 2017; pp. 113-148. Available online: https://repositorio.cepal.org/bitstream/ handle/11362/42017/S1700275_es.pdf?sequence=1\&isAllowed=y (accessed on 21 March 2019).

8. Padilla Pérez, R. El fortalecimiento de cadenas de valor de productos primarios y agroindustriales. In Política Industrial Rural y Fortalecimiento de Cadenas de Valor; Padilla Pérez, R., Ed.; Libros CEPAL N. 145, LC/PUB.2017/11-P; Comisión Económica para América Latina y el Caribe (CEPAL): Santiago, Chile, 2017; pp. 171-200, ISBN 978-92-1-058589-7. Available online: https:// repositorio.cepal.org/bitstream/handle/11362/42017/S1700275_es.pdf?sequence=1\&isAllowed=y (accessed on 15 March 2021).

9. Corominas, A. Supply chains: What they are and the new problems they raise. Int. J. Prod. Res. 2013, 51, 6828-6835. [CrossRef]

10. Prado-Carpio, E. Gestión de Agronegocios y el Desempeño de la Cadena de Valor de la Concha Prieta Anadara tuberculosa. Ph.D. Thesis, Universidad del Zulia, Zulia, Venezuela, 2020; p. 303. Available online: https://www.researchgate.net/publication/3533 52826_Tesis_Doctoral_en_el_Doctorado_de_Ciencias_Agrarias (accessed on 4 August 2021). [CrossRef]

11. Hines, P. Integrated Materials Management: The Value Chain Redefined. Int. J. Logist. Manag. 1993, 4, 13-22. [CrossRef]

12. Ocampo, P.; Prada, R. Orientación a la cadena de suministro y su relación con diferentes grupos de interes. Una revisión bibliográfica. Rev. Tecnol. 2016, 15, 117-128. Available online: https://www.researchgate.net/publication/316322314_Orientacion_a_ la_cadena_de_suministro_y_su_relacion_con_diferen-tes_grupos_de_interes_Una_revision_bibliografica_Orientation_to_the_ supply_chain_and_its_relationship_with_different_interest_groups_A_bi (accessed on 1 May 2020). [CrossRef]

13. Briz, J.; de Felipe, I. La Cadena de Valor Agroalimentaria. Análisis Internacional de Casos Reales; Editorial Agrícola Española S.A.: Madrid, Spain, 2011; p. 37, ISBN 978-84-92928-07-1. Available online: https://www.researchgate.net/profile/Jose-AcevedoSuarez/publication/311992835_Modelo_de_Referencia_de_la_Red_de_Valor_en_Latinoamerica/links/5867c85608ae8fce491 5c5a9/Modelo-de-Referencia-de-la-Red-de-Valor-en-Latinoamerica.pdf (accessed on 1 May 2020).

14. Quintero, J.; Sánchez, J. La cadena de valor: Una herramienta del pensamiento estratégico. Telos 2006, 8, 377-389. Available online: https: / / www.redalyc.org/articulo.oa?id=99318788001 (accessed on 22 April 2019).

15. Organización de las Naciones Unidas para la Alimentación y la Agricultura (FAO). Desarrollo de Cadenas de Valor Alimentarias Sostenibles: Principios Rectores; FAO: Roma, Italia, 2015; p. 106, ISBN 978-92-5-308481-4. Available online: http:/ / www.fao.org/3/ i3953s /i3953s.pdf (accessed on 5 January 2020).

16. Asociación Latinoamericana de Integración (ALADI). Fortalecimiento de Cadenas del Mapa Logistico y Productivo del Ecuador; Asistencia Técnica y Capacitación. Informe del proyecto. Publicación DAPMDER $\mathrm{N}^{\circ} 14-10$ Fortalecimiento de cadenas del mapa logístico y productivo del Ecuador; ALADI: Montevideo, Uruguay, 2011; p. 63. Available online: http:/ /www2.aladi.org/ nsfaladi/Estudios.nsf/cbb2f4bc1f0ccfec032574a3005461cc/d4b359866da1aa190325788e006a8bad/\$FILE/14-10.pdf (accessed on 5 February 2019). 
17. Poveda, D.; Piedrahita, Y. La Industria Camaronera de Ecuador Superando Numerosos Obstáculos en 2020; Global Seafood Alliance: Portsmouth, NH, USA, 2020. Available online: https://www.globalseafood.org/advocate/la-industria-camaronera-deecuador-superando-numerosos-obstaculos-en-2020/C\%C3\%A1mara\%20Nacional\%20de\%20Acuacultura-2020 (accessed on 11 February 2021).

18. MacKenzie, C. The fisheries for mangrove cockles, Anadara spp., from Mexico to Peru, with descriptions of their habitats and biology, the fishermen's lives, and the effects of shrimp farming. Mar. Fish. Rev. 2001, 63, 1-39. Available online: https://spo.nmfs.noaa.gov/sites/default/files/pdf-content/MFR/mfr631/mfr6311.pdf (accessed on 14 July 2021).

19. Prado-Carpio, E.; Castro-Armijos, C.; Rentería-Minuche, P.; Coronel-Reyes, J.; Paladines-Amaiquema, J.; Martínez-Soto, M. Agronegocio conchero (Anadara tuberculosa): Aspectos socioeconómicos, Archipiélago de Jambelí. Rev. Cumbres 2019, 5, 79-88. Available online: https://investigacion.utmachala.edu.ec/revistas/index.php/Cumbres/article/view/455 (accessed on 21 May 2018). [CrossRef]

20. López-Rodríguez, F. Mangrove in Ecuador: Conservation and Management Strategies, Coastal Environments; IntechOpen: London, UK, 2021; Available online: https:/ / www.intechopen.com/books/coastal-environments/mangrove-in-ecuador-conservation-andmanagement-strategies (accessed on 22 January 2021). [CrossRef]

21. Prado-Carpio, E.; Martínez-Soto, M.E.; Rodríguez-Monroy, C.; Núñez-Guerrero, Y.; Quiñonez-Cabeza, M.; Nazareno-Veliz, I.; Egas-Moreno, F.; Castillo-Cabeza, N. Description of the production chain of the concha prieta Bivalve Mollusc "Anadara tuberculosa". EasyChair Preprint 2020, 3749, 1-10. Available online: https://www.researchgate.net/publication/342802503 (accessed on 13 February 2020).

22. Tamayo y Tamayo, M. El Proceso de Investigación Científica, 4th ed.; Limusa Noriega Editores: México, 2003; p. 435. Available online: https: / / es.slideshare.net/sarathrusta/el-proceso-de-investigacion-cientifica-mario-tamayo-y-tamayo1 (accessed on 20 October 2020).

23. Hernández-Sampieri, R.; Fernandez Collado, C.; Baptista Lucio, P. Metodología de la Investigación, 4th ed.; McGraw Hill Interamericana Editores: Mexico, 2006; p. 634, ISBN 970-10-5753-8. Available online: https:/ /www.academia.edu/22160196/Metodologia_ de_la_investigacion_sampieri_(accessed on 21 January 2020).

24. Zambrano, R.; Flores, L.; Mora, E. Cambios espacio-temporales en los rendimientos de pesca de concha en el archipiélago de Jambelí, Ecuador. Técnica Rev. Agrocienc. 2017, 7-15. Available online: http://revistas.utm.edu.ec/index.php/latecnica/article/ view /949 (accessed on 3 April 2019). [CrossRef]

25. Badii, M.H.; Castillo, J.; Guillen, A. Tamaño óptimo de la muestra. Innov. Neg. 2008, 5, 53-65. Available online: http: //revistainnovaciones.uanl.mx/index.php/revin/article/view/199 (accessed on 21 March 2019).

26. Prado-Carpio, E. Gestión de agronegocios y el desempeño de la cadena de valor de la concha prieta Anadara tuberculosa. Quantitative Data and Questionaires. Ph.D. Thesis, Universidad del Zulia, Zulia, Venezuela, 2020; p. 303. Available online: https: //www.researchgate.net/publication/354600788_Data_Tesis_Doctoral_Eveligh_Prado-Carpio (accessed on 20 September 2021).

27. Martínez-Soto, M.E. Desarrollo de un modelo de gestión del conocimiento en la cadena de suministro de la industria agroalimentaria. Ph.D. Thesis, Universidad Politécnica de Madrid, Escuela Técnica Superior de Ingenieros Industriales, Madrid, Spain, 2011; p. 271. Available online: http:/ / oa.upm.es/6199/1/MOISES_ENRIQUE_MARTINEZ_SOTO.pdf (accessed on 20 October 2020).

28. Prado-Carpio, E.; Martínez-Soto, M.E.; Morris-Díaz, A.; Castro-Armijos, A.; Renteria-Minuche, P.; Coronel-Reyes, J.; Rodríguez Monroy, C. Importancia de la producción de la concha prieta (Anadara tuberculosa) en las costas ecuatorianas. Rev. Espam Cienc. 2020, 11, 34-46.

29. Feres, J.X.; Mancero, X. El método de las Necesidades Básicas Insatisfechas (NBI) y Sus Aplicaciones en América Latina; Serie Estudios Estadísticos y Prospectivos 7; Comisión Económica para América Latina y el Caribe-CEPAL, División de Estadística y Proyecciones Económicas: Santiago, Chile, 2001; p. 52, ISBN 9213217919. Available online: https:/ /www.cepal.org/es/publicaciones/4784 -metodo-necesidades-basicas-insatisfechas-nbi-sus-aplicaciones-america-latina (accessed on 30 May 2019).

30. Prado-Carpio, E.; Martínez-Soto, M.; Rodríguez-Monroy, C.; Morris-Díaz, A. Agribusiness management characterization and performance of the value chain in the production of the "concha prieta" (Anadara tuberculosa). Proceedings in System Dynamics and Innovation in Food Networks. Int. J. Food Syst. Dyn. 2020, 63-83. Available online: https://www.researchgate.net/publication/ 352573540_INTERNATIONAL_JOURNAL_ON_FOOD_SYSTEM_DYNAMICS_Structural_Equations_Model_of_the_Concha_ Prieta_Anadara_tuberculosa_Agribusiness_Management_and_Value_Chain_Performance_in_the_Ecuadorian_Mangroves (accessed on 2 January 2021). [CrossRef]

31. Teutli-Hernández, C. Una Aproximación a la Integración de Escalas Ecológicas Para la Restauración de Ecosistemas de Manglar. Ph.D. Thesis, Universitat de Barcelona, Facultad de Biología, Biología, Spain, 2017; p. 191. Available online: https:/ / www.google.co.ve/search?q=15.\%09Teutli-Hern\%C3\%A1ndez.+2017.+Una+Aproximaci\%C3\%B3n+a+la+ integraci $\%$ C3\%B3n+de+escalas+ecol\%C3\%B3gicas+para+la+restauraci $\%$ C3\%B3n+de+ecosistemas+de+manglar.+Tesis+ Doctoral.+Universitat+de+Barcelona\&sxsrf (accessed on 4 January 2021).

32. Olivo-Garrido, M.L. Conflictos de uso en Áreas bajo Régimen de Administración Especial: Una metodología de conciliación. Master's Thesis, Universidad Simón Bolívar, Caracas, Venezuela, 1992; p. 160.

33. Olivo-Garrido, M.L. El Potencial Incremento del Nivel del mar como un Resultado del Cambio Climático Global en Venezuela: Caso Cabo Codera-Laguna de Tacarigua, Estado Miranda. Ph.D. Thesis, Universidad Central de Venezuela, Facultad de Humanidades y Educación, Caracas, Venezuela, 2009; p. 300. 
34. Villón, H. Contaminación por coliformes totales y Escherichia coli, en concha (Anadara tuberculosa y Anadara similis) Jambelí, provincia El Oro. Trabajo de Titulación Previo a la Obtención del Grado de Ingeniera Ambiental. Universidad de Guayaquil, Facultad de Ciencias Naturales, Guayaquil, Ecuador. 2019. Available online: http://repositorio.ug.edu.ec/handle/redug/39616 (accessed on 28 December 2020).

35. Sorroza Ochoa, L.; Velásquez López, P.; Santacruz Reyes, R.; Echeverría Espinoza, E.; Yánez Morocho, M.; Galo Solano, M. Disminución/reducción de la carga bacteriana en la concha negra Anadara tuberculosa para consumo humano. Rev. Espac. 2018, 39, 34-39. Available online: https:/ / www.revistaespacios.com/a18v39n45/a18v39n45p34.pdf (accessed on 2 February 2021).

36. Benítez Pardo, D. Forestación artificial con mangles en isletas de dragados en una región semiárida de México. Ph.D. Thesis, Instituto Politécnico Nacional, Centro Interdisciplinario de Ciencias Marinas, La Paz, Mexico, 2007; p. 123. Available online: https:/ / www.repositoriodigital.ipn.mx/bitstream/123456789/13739/1/benitesp2.pdf (accessed on 21 March 2021).

37. Benitez-Pardo, D.; Flores-Verdugo, F.J.; Casas-Valdez, M.; Hernández-Carmona, G.; Valdez-Hernández, J.I.; Gómez-Muñoz. Forestación de isletas artificiales utilizando dos especies de mangles, en una laguna costera del Golfo de California, México. V. Bot. Sci. 2015, 93, 165-174. [CrossRef]

38. Febles-Patrón, J.L.; Novelo López, J.; Batllori Sampedro, E. Pruebas de reforestación de mangle en una ciénaga costera semiárida de Yucatán, México. Maderas Bosques 2009, 15, 65-86. [CrossRef]

39. Herrera Silveira, J.; Teutli, C.; Gómez Ruiz, P.; Comín, F.A. Restauración ecológica de manglares de México. In Gobernanza y Manejo de las Costas y Mares ante la Incertidumbre, Una Guía para Tomadores de Decisiones; Project: Recuperación de Servicios Ambientales en Manglares Restaurados de la Costa Norte de Yucatán Universidad Autónoma de Campeche: México, April 2020; Chapter 33; pp. 649-674. Available online: https://www.researchgate.net/publication/340487905_Restauracion_ecologica_de_ manglares_de_Mexico (accessed on 15 March 2021).

40. Teutli-Hernández, C.; Herrera-Silveira, J.A.; Cisneros-de la Cruz, D.J.; Roman-Cuesta, R. Guía Para la Restauración Ecológica de Manglares: Lecciones Aprendidas; Proyecto, Mainstreaming Wetlands into the Climate Agenda: A multi-level approach (SWAMP); CIFOR/CINVESTAV-IPN/UNAM-Sisal/PMC: México, 2020; p. 42. Available online: https://www.cifor.org/publications/pdf_ files/Books/2020-Guia-SWAMP.pdf (accessed on 22 February 2021).

41. Mendoza, O.; Peralta, Y.T. Crianza de Anadara tuberculosa (Sowerby, 1833) haciendo uso de corrales, en su medio natural. Rev. Manglar 2003, 1, 77-85.

42. Galdámez, A.; Pacheco, P.; Pérez, I.; Kino, S. Guía para la producción de Anadara spp. 2006-2007: Producción artificial de semillas, cultivo intermedio y cultivo de A. tuberculosa y A. grandis; Proyecto JICA-CENDEPESCA. CENDEPESCA/Ministerio de Agricultura y Ganadería (MAG): San Salvador, El Salvador, 2007; p. 42.

43. Espinosa, G.S.; Delgado Hernández, M.F.; Orobio Riofrío, B.; Mejía-Ladino, L.M.; Gil-Agudelo, D.L. Estado de la población y valoración de algunas estrategias de conservación del recurso piangua Andara tuberculosa (Sowerby) en sectores de Bazán y Nerete, costa pacífica nariñense de Colombia. Bol. Invest. Mar. Cost. 2010, 39, 161-176.

44. Tapia Zavala, F. Costos de conservación del manglar: Casos Las Huacas y Pongalillo, en la provincia de El Oro, al sur de Ecuador. Investigation 2020, 13, 65-76. [CrossRef]

45. FAO-Organización de las Naciones Unidas para la Alimentación y la Agricultura. Estado Actual del Cultivo y Manejo de Moluscos Bivalvos y su Proyección Futura. Factores Que Afectan su Sustentabilidad en América Latina. Taller Técnico Regional de la FAO, Puerto Montt, Chile, 20-24 August 2007. p. 377, ISBN 978-92-5-306115-0. Available online: http:/ /www.fao.org/3/ai0444s.pdf (accessed on 4 January 2018).

46. Sandoval, E.; Saborío, A. Calidad bacteriológica del agua en los sitios de recolección de "conchas negras" (Anadara tuberculosa y Anadara similis) en Chinandega, Nicaragua. Encuentro 2017, XL, 30-47. Available online: https://www.researchgate. net/publication/317136134_Calidad_bacteriologica_del_agua_en_los_sitios_de_recoleccion_de_conchas_negras_Anadara_ tuberculosa_y_Anadara_similis_en_Chinandega_Nicaragua (accessed on 21 March 2021). [CrossRef]

47. Lee, R.; Lovatelli, A.; Ababouch, L. Depuración de Bivalvos: Aspectos Fundamentales y Prácticos; Fisheries and Aquaculture Management Division. Número de Serie: 1014-1138; FAO Documento Técnico de Pesca. $N^{\circ}$ 511; FAO-Organización de las Naciones Unidas para la Alimentación y la Agricultura: Rome, Italy, 2010; p. 153, ISBN 9789253060061. Available online: http:/ / www.fao.org/3/i0201s/i0201s.pdf (accessed on 14 January 2020).

48. Quiñonez-Cabeza, M.R.; Nazareno-Veliz, I.T.; Camacho-Marín, R.A.; Cedeño-Coveña, M.V. Proceso de comercialización y extracción de productos de manglar, San Lorenzo-Ecuador. Rev. Venez. Gerenc. 2020, 25, 885-899. [CrossRef]

49. Aguilar Pérez, E.M.; Córdova Zárate, S.E. Valor Compartido y Sostenibilidad en la Cadena de Valor de la Asociación de Extractores de Mariscos y Pesca Submarina en Ancón al 2016. Tesis Pregrado, Licenciatura en Ciencias Administrativas, Facultad Ciencias Administrativas, Universidad Nacional del Callao, Perú. p. 195. Available online: http://repositorio.unac.edu.pe/handle/ UNAC/3171 (accessed on 12 April 2021).

50. Vidal, I. El principio de valor compartido de Porter y Kramer. Boletín Cent. Investig. Econ. Soc. CIES-Univ. Barc 2011, 92, 1-6. Available online: http://brd.unid.edu.mx/recursos/Maestria/Admin_Neg/Titulacion/El_principio_de_valor_compartido.pdf? $603 f 00$ (accessed on 2 March 2021).

51. Veronesi Burch, M.; Maes, S. Impulsar la Actividad Empresarial a lo Largo de la Cadena de Valor de la Pesca; Dirección General de Asuntos Marítimos y Pesca, Director General. Folleto N 12; Comisión Europea: Bruselas, Belgium, 2021; p. 50. ISBN 978-92-79-651960. Available online: https://webgate.ec.europa.eu/fpfis/cms/farnet2/sites/default/files/publication/es_farnetguide12.pdf (accessed on 15 February 2021). ISSN 2363-4049. [CrossRef] 
52. Ovalles Toledo, L.V.; Moreno Freites, Z.; Olivares Urbina, M.A.; Silva Guerra, H. Habilidades y capacidades del emprendimiento: Un estudio bibliométrico. Rev. Venez. Gerenc. 2018, 23, 217-234. Available online: https://www.redalyc.org/jatsRepo/290/2905 5767013/html/index.html (accessed on 4 December 2020).

53. Beitl, C.M. Adding environment to the collective action problem: Individuals, civil society, and the mangrove-fishery commons in Ecuador. World Dev. 2014, 56, 93-107. Available online: https:/ /www.sciencedirect.com/science/article/abs/pii/S0305750x1 3002386 (accessed on 5 May 2021). [CrossRef]

54. Beitl, C.M. Navigating over space and time: Fishing effort allocation and the development of customary norms in an open-access mangrove estuary in Ecuador. Hum. Ecol. 2014, 42, 395-411. [CrossRef]

55. Beitl, C.M. Cockles in custody: The role of common property arrangements in the ecological sustainability of mangrove fisheries on the Ecuadorian coast. Int. J. Commons 2011, 5, 485-512. Available online: https:/ / www.thecommonsjournal.org/articles/10.1 8352/ijc.285/ (accessed on 1 April 2021). [CrossRef]

56. Carchi, X.; Gaibor, N.; Moreno, J.; Alemán, C.; Ramírez, L. Los acuerdos de uso sostenible y custodia de manglar y su impacto en el recurso concha prieta (Anadara tuberculosa) en la provincia de Esmeraldas. Molina Moreira, N. \& Galvis, F. (Comp). Primer Congreso Manglares de América. Universidad Espíritu Santo. Samborondón-Ecuador. 2019. Available online: https: / / manglaresdeamerica.com/index.php/ec/article/view/30 (accessed on 27 January 2021).

57. López-Rodríguez, F.; Benítez, A.; Jurrius, I. Efectividad de manejo de Acuerdos de Uso Sustentable y Custodia de Manglar en la provincia de El Oro. Martha Molina Moreira (Comp.) Primer Congreso Manglares de América, Guayaquil, Ecuador. 2019. Available online: http:/ / manglaresdeamerica.com/index.php/ec/article/view/14/25 (accessed on 2 April 2021).

58. Herrera Jiménez, G. Fondos Para la Investigación y Desarrollo Tecnológico de Moluscos Bivalvos en Chile: Resultados y Proyecciones. Estado Actual del Cultivo y Manejo de Moluscos Bivalvos y su Proyección Futura. Factores Que Afectan su Sustentabilidad en América Latina. Taller Técnico Regional de la FAO 20-24 de agosto de 2007. FAO Actas de Pesca y Acuicultura: Puerto Montt, Chile. Available online: http:/ /www.fao.org/3/i0444s/i0444s01.pdf (accessed on 4 September 2020).

59. Galdámez Castillo, A.M.; Pacheco Reyes, S.P.; Pérez García, I.M.; Kino, S. Guía Para la Producción de Anadara spp. $2006-2007$. Centro de Desarrollo de la Pesca y Acuicultura (CENDEPESCA), Ministerio de Agricultura y Ganadería (MAG), San Salvador, Republica de El Salvador, Centro América y la Agencia de Cooperación Internacional del Japón (JICA) a través del Proyecto para el Desarrollo de la Acuicultura de Moluscos en la República de El Salvador, Oficina Regional CENDEPESCA. 2017. Available online: https:/ / www.jica.go.jp/project/elsalvador/2271029E1/materials/pdf/2007/2007_01_01.pdf (accessed on 4 March 2021).

60. Fundación Heifer Ecuador. Proceso de Selección y Contratación de la Consultoría para la Línea Base del Proyecto: Competitividad de las Comunidades Concesionarias de Manglares en el Golfo de Guayaquil. 2018. Available online: www.heifer-ecuador.org/ TDR-CONSULTORIA-LINEA-BASE-MANGLAR-EXTE (accessed on 28 April 2019).

61. Instituto Público de Investigación de Acuicultura y Pesca. Reporte Web-Abril 2021, Recurso Concha (Anadara tuberculosa y Anadara similis) en la Provincia de El Oro. Available online: http://www.institutopesca.gob.ec/concha (accessed on 2 November 2020).

62. Ministerio del Ambiente de Ecuador-MAE. Entrega Incentivos Económicos a Beneficiarios de Socio Manglar. Gobierno del Encuentro. MAE a Través de su Programa de Incentivos Socio Bosque, Capítulo Socio Manglar. Available online: https: //www.ambiente.gob.ec/mae-entrega-incentivos-economicos-a-beneficiarios-de-socio-manglar (accessed on 3 January 2021).

63. Periódico Digital La Hora. Conchas de San Lorenzo llegan a Estados Unidos. 28 May 2021. Available online: https://www. lahora.com.ec/conchas-de-san-lorenzo-llegan-a-estados-unidos (accessed on 8 June 2021). 